\title{
Kandungan Antioksi dan Asam Askorbat pada Jus Buah-Buahan Tropis
}

\author{
Novi Febrianti, Irfan Yunianto, Risanti Dhaniaputri \\ Progam Studi Pendidikan Biologi, FKIP, Universitas Ahmad Dahlan \\ Kampus III, J1. Prof. Dr. Soepomo, SH, Yogyakarta, 55164 Indonesia \\ surat elektronik: novifebrianti@pbio.uad.ac.id
}

\begin{abstract}
ABSTRAK
Tropical fruits are rich in nutrients and phytochemicals that benefit our health. As source of antioxidant, regular consumption of fruits will be useful in avoiding many degenerative diseases particularly caused by free radicals. The good effects of antioxidants vary from repairing tissue damages in respiratory system, excretory system as well as reproductive system. Ascorbic acid is one potent antioxidant that has been recorded for history. Known as Vitamin C, its concentration in fruits has been a primary consideration for people to choose what kind of fruit they are going to consume. This experiment's result exhibited different levels of ascorbic acid in some topical fruits. Average concentration of ascorbic acid from the highest to lowest was obtained in orange, guava, apple, papaya, tamarind and mango with their contents of 96,8; 49,86; 49,57; 48,4 and 4I,06 mg/IOOg, respectively. This result would be a baseline in setting the best fruit combination to obtain maximum effects of antioxidant.
\end{abstract}

Kata kunci: tropical fruits, antioxidants, ascorbic acid.

\section{Pendahuluan}

Buah-buahan merupakan sumber bahan alami yang mengandung berbagai senyawa antioksi dan tinggi. Dibandingkan dengan antioksidan sintetis, antioksidan alami umumnya lebih aman untuk dikonsumsi dan dapat meningkatkan derajat kesehatan tubuh.Indonesia merupakan salah satu dari delapan pusat keanekaragaman genetika tanaman dunia, khususnya buah-buahan tropis yang berpotensi sebagai sumber antioksidan alami.

Buah-buahan tropis sebagai sumber antioksidan alami berpotensi untuk memperbaiki kerusakan sistem pernafasan dan sistem reproduksi. Febrianti dan Widayati (20I4) mendapatkan bahwa pemberian jus buah pepaya pada mencit yang dipaparkan asap rokok menyebabkan struktur pulmonya kembali normal. Penelitian Marianti (2013) serta Imam \& Juwono (2006) mendapatkan bahwa jus tomat juga mempunyai efek positif untuk mencegah kerusakan pulmo dan meningkatkan motilitas spermatozoa mencit yang dipaparkan asap rokok karena aktivitas antioksidannya yang tinggi.

Sejauh ini, belum dilakukan penelitian yang komprehensif mengenai potensi antioksidan berbagai jenis buah-buahan tropis yang ada di Indonesia untuk melindungi berbagai sistem organ pada hewan uji akibat paparan polutan. Sebagai langkah awal, penelitian ini bertujuan mengetahui kadar kandungan antioksidan asam askorbat dari jus buah-buahan tropis.

Penentuan konsentrasi asam askorbat diperlukan untuk mengetahui potensi antioksidan dari buah-buahan tropis tersebut. Setelah mendapatkan gambaran aktivitas antioksidan tersebut maka langkah penting selanjutnya adalah mengetahui efektifitas senyawa antioksidan pada hewan uji terpapar polutan untuk melihat efek protektifnya terhadap sistem pernafasan.

Telah lama diketahui bahwa buah-buahan merupakan sumber antioksidan alami yang membawa berbagai manfaat bagi tubuh manusia. Gregoris et al. (2013) telah meneliti sifat antioksidan berbagai jenis buah-buahan tropis Brazil. Mahattanatawee et al (2006) mendapatkan bahwa berbagai jenis buah-buahan tropis Florida mempunyai aktivitas antioksidan yang bervariasi. Penelitian Ashraff et al (20II) mendapatkan bahwa berbagai varietas durian lokal yang tumbuh Penang mempunyai potensi antioksidan yang tinggi. Nurliyana et al (2010) mendapatkan bahwa daging dan kulit buah naga juga memiliki aktivitas antioksidan yang cukup tinggi.

Ada berbagai variasi jenis antioksidan yang terdapat dalam buah-buahan. Senyawa-senyawa antioksidan tersebut bekerja dengan cara menghalangi oksidasi 
selular yang disebabkan oleh spesies oksigen reaktif. Sebenarnya tubuh kita memiliki senyawa antioksidan (antioksidan endogen) untuk melawan kerusakan yang ditimbulkan oleh spesies oksigen reaktif, tetapi kondisi saat ini dimana radikal bebas yang berasal dari lingkungan seperti asap rokok, polusi udara, obat-obatan dan lain-lain sangat banyak maka tubuh membutuhkan antioksidan yang didatangkan dari luar. Prinsip utama aktivitas antioksidan adalah ketersediaan elektron untuk menetralisir radikal bebas. Senyawaantioksidan yang paling berlimpah pada buah-buahan adalah karotenoid, flavonoid, fenolik, vitamin $\mathrm{C}$, vitamin $\mathrm{E}$, vitamin $\mathrm{A}$,dan betalain (Nurliyana et al. 2010; Ashraf et al., 2009).

Antioksidan yang terkandung di dalam buah-buahan mempunyai sangat banyak manfaat untuk kesehatan manusia. Menurut Antolovic et al. (2002) dalam Gregoris et al. (2013) antioksidan adalah satu mekanisme pertahanan yang paling penting untuk melawan radikal bebas. Dewi (201I) meneliti pengaruh ekstrak buah mengkudu terhadap histopatologi testis tikus putih yang dipapar asap rokok. Hasil penelitiannya menunjukkan bahwa pemberian perlakuan ekstrak buah mengkudu mempunyai pengaruh yang signifikan terhadap tubulus seminiferus. Penelitian Mariyanti (2013) mendapatkan bahwa jus tomat mempunyai efek positif untuk mencegah kerusakan pulmo yang dipaparkan asap rokok karena aktivitas antioksidannya yang tinggi. Penelitian Febrianti \& Ardiansyah (2013) dan Febrianti \& Ariyana (2013) mendapatkan hasil bahwa buah jambu biji merah dan pepaya dapat memperbaiki kerusakan histopatologis tubulus seminiferus testis serta mampu meningkatkan jumlah spermatozoa mencit yang dipaparkan asap rokok. Febrianti dan Widayati (2014) mendapatkan bahwa pemberian jus buah pepaya dengan dosis $0,26 \mathrm{ml} /$ hari pada mencit yang dipaparkan asap rokok menyebabkan struktur pulmonya kembali normal.

Dari berbagai penelitian terdahulu telah diketahui potensi buah-buahan tropis sebagai sumber antioksidan. Penelitian-penelitian yang pernah dilakukan tersebut berasal dari luar Indonesia, yaitu Brazilia, Florida, dan Malaysia. Belum ada penelitian yang komprehensif mengenai potensi antioksidan dari berbagai jenis buah tropis yang tumbuh di Indonesia.Oleh sebab itu, diperlukan penelitian untuk mengetahui potensi antioksidan pada berbagai jenis buah tropis yang ada di DIY dan sekitarnya. Secara biokimia Vitamin C (asam askorbat) adalah senyawa dengan rumus $\mathrm{C} 6 \mathrm{H} 8 \mathrm{O} 6$ dengan struktur cicin lakton 6-karbon yang dapat disintesa dari glukosa dalam hatihewan mamalia pada umumnya, tetapi tidak pada manusia, primata dan guinea pig. Spesies ini dalam hatinya tidak memiliki kemampuan untuk mensintesis enzym Gulonolakton oksidase. Hal ini disebabkan karena DNA yang mengkode untuk sintesa.

Enzym ini telah mengalami mutasi. Akibatnya hati manusia tidak dapat mensintesis vitamin $\mathrm{C}$ sendiri, melainkan harus mengkonsumsi buah dan sayuran sebagai sumber vitamindan mineral. Defisiensi vitamin menyebabkan dampak klinis yang cukup luas, misalnyakekurangan vitamin $\mathrm{C}$ dapat menyebabkan seseorang terserang penyakit scorbut yang kita kenal dengan sariawan (Wijaya, 20I4).

Vitamin C juga disebut sebagai elektron donor (pemberi elektron) sehingga termasuk dalam senyawa anti-oksidan. Vitamin C sebagai pemberi elektron, juga ini berarti sebagai agenreduktor, berasal dari sifat ikatan ganda antara C-2 dan C-3 dari cicin lakton 6karbontersebut. Vitamin $\mathrm{C}$ dapat mencegah senyawasenyawa lain mengalami oksidasi. Secara alamiah vitamin C itu sendiri yang mengalami oksidasi (Wijaya, 20I4).

\section{Metode Penelitian}

\section{Koleksi Buah Tropis}

Berbagai jenis buah tropis yang digunakan pada penelitian ini, yaitu: jeruk, pepaya, asam jawa, apel, jambu, dan mangga didapatkan dari perkebunan buah atau pasar buah yang berada di Daerah Istimewa Yogyakarta dan sekitarnya.

\section{Persiapan dan Ekstraksi Buah}

Persiapan dan ekstraksi buah mengacu pada metode Nurliyana (2010) dengan beberapa modifikasi.Buahbuahan tropis dicuci dan dikupas untuk memisahkan kulit dan daging buahnya.Daging buah diblender untuk mendapatkan sediaan seperti pasta selama beberapa menit. Campuran ini dikering untuk mengurangi kelembaban sampel agar proses ekstraksi berjalan lebih efisien. Sampel yang sudah homogen dituangkan ke dalam tabung volumetrik dan ditambahkan akuades sampai $250 \mathrm{ml}$. Campuran ini diaduk dengan menggunakan pengaduk mekanik selama beberapa hari sebelum disaring menggunakan kertas saring Whatman No. 4. Setelah itu filtrat diuapkan menggunakan rotari evaporator selama beberapa jam pada suhu $40^{\circ} \mathrm{C}$ untuk menghilangkan pelarut, kemudian dilakukan lyofilisasi untuk menghilangkan sisa air yang terdapat di dalam substrat.

\section{Uji Asam Askorbat}

Metode yang dilakukan dalam pengujian kandungan asam askorbat pada sampel buah yaitu terbagi dalam langkah-langkah berikut ini :

\section{a. Ekstrak Sampel}

Sebanyak \pm I g sampel bubuk buah dimasukkan dalam labu takar $10 \mathrm{ml}$ dan ditambahkan aquades sampai tera, kemudian disaring.

\section{b. Pembuatan Larutan Iodium}

Larutan iodium 0,0I $\mathrm{N}$ dibuat dengan cara mencampurkan 2,00 gram KI dan $\mathrm{I}_{2}$, kemudian dilarutkan sampai volume I liter dengan aquades selama semalaman untuk melarutkan iod secara sempurna. 


\section{c. Penentuan Konsentrasi Asam Askorbat}

Penentuan konsentrasi asam askorbat mengikuti metode dari FAO (2015) dengan modifikasi. Sebanyak I $\mathrm{ml}$ filtrat hasil ekstraksi diencerkan ke dalam $10 \mathrm{ml}$ aquades dan diambil $2 \mathrm{ml}$ filtrate hasil pengenceran yang dimasukkan ke dalam Erlenmeyer, lalu ditambahkan dengan 0,4 ml larutan amilum (soluble starch) I\%. Larutan kemudian dititrasi dengan 0,0I $\mathrm{N}$ iodium. Titik akhir titrasi ditandai dengan perubahan warna larutan menjadi semburat biru. Larutan 0,0I $\mathrm{N}$ setara dengan $0,88 \mathrm{mg}$ asam askorbat. Konsentrasi asam askorbat dihitung dengan rumus:

$$
\begin{aligned}
& \text { Vitamin } C(\mathrm{mg} / 100 \mathrm{~g} \text { sampel } \\
& =\frac{(\text { titer }(\mathrm{ml}) \times 0,88 \mathrm{mg} \times \text { faktor pengenceran }) \times 100}{W \text { sampel }(\mathrm{g})}
\end{aligned}
$$

\section{Hasil dan Pembahasan}

Hasil rerata titrasi dari seluruh sampel buah dengan tiga kali pengulangan adalah sebagai berikut:

Tabel I. Rerata kandungan asam askorbat sampel buah

\begin{tabular}{cc}
\hline Buah & $\begin{array}{c}\text { Kandungan asam askorbat } \\
(\mathrm{mg} / \mathrm{IO0g})\end{array}$ \\
\hline Jeruk & 96,8 \\
\hline Papaya & 48,4 \\
\hline Asam jawa & 41,06 \\
Apel & 49,57 \\
Jambu & 49,86 \\
Mangga & 41,06 \\
\hline
\end{tabular}

Pengujian kandungan asam askorbat menggunakan metode titrasi iodium. Prinsip kerja metode ini adalah iodium memiliki potensial reduksi yang lebih tinggi dibandingkan dengan asam askorbat, sehingga iodium akan mengoksidasi senyawa asam askorbat dengan membentuk asam dehidroaskorbat. L-diketogulonat memiliki sifat reduktor yang lemah dibandingkan asam askorbat dan dehidroaskorbat sehingga tidak dapat dioksidasi oleh iodium. Pengujian dengan metode ini cukup mudah dan relatih murah, namun kurang efektif untuk mengukur kandungan asam askorbat, karena dalam bahan pangan terdapat komponen lain selain asam askorbat yang juga bersifat pereduksi. Senyawa tersebut mempunyai titik akhir yang sama dengan warna titik akhir titrasi asam askorbat dengan iodin. Indikator titrasi menggunakan amilum untuk mengetahui titik akhir titrasi dengan memberikan perubahan warna menjadi biru kehitaman (Monalisa, dkk. 20I3).

Dari hasil perhitungan, kandungan asam askorbat secara berurutan dari yang tertinggi yaitu didapatkan pada buah jeruk, jambu, apel dan pepaya dengan konsentrasi masing-masing adalah 96,8; 49,86; 49,57; 48,4 (mg/IOOg). Sedangkan kandungan antioksidan asam askorbat pada asam jawa kurang lebih setara dengan mangga, yaitu 4I,06 mg/I00g.
Beberapa jenis buah dikenal sebagai sumber vitamin C (asam askorbat).Jambu monyet dilaporkan mengandung vitamin C sebanyak $197 \mathrm{mg} / \mathrm{IOO} \mathrm{g}$. Sedangkan apel, jeruk manis dan mangga masing-masing mengandung vitamin $C$ sebesar $5 \mathrm{mg} / \mathrm{IOOg}, 49$ $\mathrm{mg} / \mathrm{IOOg}$, dan $6 \mathrm{I} \mathrm{mg} / \mathrm{IOOg}$ (Aina dan Suprayogi, 20II).

Asam askorbat dikenal memiliki sifat yang mudah larut dalam air dan mudah rusak dengan pemanasan yang terlalu lama. Beberapa faktor yang mempengaruhi konsentrasi asam askorbat pada suatu bahan makanan adalah : jangka waktu penyimpanan, paparan sinar matahari, dan faktor pemanasan (Sinaga, 20II). Sebagaimana dijelaskan oleh Almatsier (2004) bahwa proses pencucian dan pemasakan buah dengan pemanasan yang terlalu lama dapat menghilangkan kandungan asam askorbat.

Mukaromah dkk, (2010) dalam kajiannya melaporkan bahwa penambahan gula untuk memproses pembuatan sirup menggunakan buah rosella justru dapat melindungi hilangnya asam askorbat.Hal ini disebabkan sifat vitamin $\mathrm{C}$ yang merupakan senyawa reduktor, asam-asamaskorbat berada dalam keseimbangandengan asam dehidroaskorbat.Dalam suasanaasam, cincin lakton asam dehidroaskorbat teruraidengan membentuk senyawa diketogulonatsehingga vitamin C terlindung dengan adanya penambahan senyawa gula. Dengan demikian, proses pengolahan bahan/buah harus senantiasa diperhatikan agar memperoleh kadar vitamin c yang paling optimal.

Pengujian kandungan asam askorbat menggunakan metode titrasi iodium. Prinsip kerja metode ini adalah iodium memiliki potensial reduksi yang lebih tinggi dibandingkan dengan asam askorbat, sehingga iodium akan mengoksidasi senyawa asam askorbat dengan membentuk asam dehidroaskorbat. L-diketogulonat memiliki sifat reduktor yang lemah dibandingkan asam askorbat dan dehidroaskorbat sehingga tidak dapat dioksidasi oleh iodium. Pengujian dengan metode ini cukup mudah dan relatih murah, namun kurang efektif untuk mengukur kandungan asam askorbat, karena dalam bahan pangan terdapat komponen lain selain asam askorbat yang juga bersifat pereduksi. Senyawa tersebut mempunyai titik akhir yang sama dengan warna titik akhir titrasi asam askorbat dengan iodin. Indikator titrasi menggunakan amilum untuk mengetahui titik akhir titrasi dengan memberikan perubahan warna menjadi biru kehitaman (Monalisa, dkk. 2013).

Berdasarkan hasil perhitungan, kandungan asam askorbat secara berurutan dari yang tertinggi yaitu didapatkan pada buah jeruk, jambu, apel dan pepaya dengan konsentrasi masing-masing adalah 96,8; 49,86; 49,57; 48,4 (mg/IO0g). Sedangkan kandungan antioksidan asam askorbat pada asam jawa kurang lebih setara dengan mangga, yaitu 41,06 mg/I00g.

Beberapa jenis buah dikenal sebagai sumber vitamin C (asam askorbat).Jambu monyet dilaporkan mengandung vitamin C sebanyak $197 \mathrm{mg} / \mathrm{I} 00 \mathrm{~g}$. Sedangkan apel, 
jeruk manis dan mangga masing-masing mengandung vitamin C sebesar $5 \mathrm{mg} / \mathrm{IO0g}, 49 \mathrm{mg} / \mathrm{IO0g}$, dan $6 \mathrm{I}$ $\mathrm{mg} / \mathrm{IOOg}$ (Aina dan Suprayogi, 20I I).

Asam askorbat dikenal memiliki sifat yang mudah larut dalam air dan mudah rusak dengan pemanasan yang terlalu lama. Beberapa faktor yang mempengaruhi konsentrasi asam askorbat pada suatu bahan makanan adalah : jangka waktu penyimpanan, paparan sinar matahari, dan faktor pemanasan (Sinaga, 20II). Sebagaimana dijelaskan oleh Almatsier (2004) bahwa proses pencucian dan pemasakan buah dengan pemanasan yang terlalu lama dapat menghilangkan kandungan asam askorbat.

Mukaromah dkk, (20I0) dalam kajiannya melaporkan bahwa penambahan gula untuk memproses pembuatan sirup menggunakan buah rosella justru dapat melindungi hilangnya asam askorbat.Hal ini disebabkan sifat vitamin $\mathrm{C}$ yang merupakan senyawa reduktor, asamasamaskorbat berada dalam keseimbangandengan asam dehidroaskorbat.Dalam suasanaasam, cincin lakton asam dehidroaskorbat teruraidengan membentuk senyawa diketogulonatsehingga vitamin $\mathrm{C}$ terlindung dengan adanya penambahan senyawa gula. Dengan demikian, proses pengolahan bahan/buah harus senantiasa diperhatikan agar memperoleh kadar vitamin $c$ yang paling optimal.

\section{Simpulan}

Konsentrasi asam askorbat bervariasi pada berbagai jenis buah.Nilai konsentrasi asam askorbat tertinggi hingga terendah secara berturut-turut ditemukan pada buah jeruk, jambu, apel dan pepaya, Sedangkan kandungan antioksidan asam askorbat pada asam jawa kurang lebih setara dengan mangga. Konsentrasi asam askorbat juga dipengaruhi oleh beberapa faktor yaitu: jangka waktu penyimpanan buah, paparan sinar matahari, dan faktor pemanasan serta pengolahan.

\section{Daftar Pustaka}

Almatsier, S. 2004. Prinsip Dasar Ilmu Gizi.Gramedia Pustaka Utama. Jakarta

Ashraff, M. A., M.J. Maah, I. Yusoff, K. Mahmood, \& A. Wajid, 20I I, Study of Antioxidant Potential of Tropical Fruit, Int.Journal of Bioscience, Biochemistry and Bioinformatics I(I) 53-57.

Dewi, E.R.S., 20II, Pengaruh pemberian ekstrak buah mengkudu terhadap histopatologi testis tikis putih setelah menghirup asap rokok, Bioma I (2)I I3-I2I

FAO. 2015. Ascorbic Acid.http://www.fao.org/ag/agn/jecfa-additives $\angle$ specs/MonographI/Additive-043.pdf. Diakses pada tanggal I0 Juni 2015.

Febrianti, N., \&Ariyana, A.I.P. 20I4, Effects of Carica papaya (Caricaceae)Fruit Juice on the Histopathological Image of Mice (Mus musculus)Testis Strain Swiss Exposed to Cigarette Smoke, Proceeding International Conference on Green World in Bussiness \& Technology.
Febrianti, N., \& Widayati, R.S. 20I4, Pengaruh Jus Buah Pepaya (Carica papaya) terhadap Gambaran Histopatologik Pulmo Mencit (Mus musculus), Bioedukatika 2 (2)

Febrianti, N. \& Y.A.Ardiansyah. 2013. Pengaruh Jus Buah Jambu Biji Merah terhadap Struktur Histopatologi Tubulus Seminiferus Mencit, Prosiding Seminar Nasional Biologi UNY

Febrianti, N., \& Widayati, R.S., 20I4, Pengaruh Jus Buah Pepaya (Carica papaya)terhadap Gambaran Histopatologik Pulmo Mencit (Mus musculus), Bioedukatika 2 (2)

Gregoris, E., G.P.P. Lima, S. Fabris, M. Bartelle, M. Sicari, \& R. Stevanato, 2013, Antioxidant Properties of Brazilian Tropical Fruits by Correlation between Different Assay, BioMed Research Int. I-8

Imam, D. \&Juwono.2006. Pengaruh Pemberian Jus BuahTomat (Lycopersicum esculentum Mill) Terhadap Motilitas Spermatozoa Mencit Balb/c Jantan yang Diberi Paparan Asap Rokok. Karya Tulis Ilmiah. Fakultas Kedokteran Universitas Diponegoro, Semarang.

Marianti, A, 2009, Aktivitas Antioksidan Jus Tomat pada Pencegahan Kerusakan Jaringan Paru-paru Mencit yang dipapar Asap Rokok, Biosaintifika, I(I): I-I0

Mahattanatawee, K, J.A. Manthey, G. Luzio, S.T. Talcott, K. Goodner, \& E.A. Baldwin, 2006, Total Antioxidant Activity and Fiber Content of Select Florida-Grown Tropical Fruit, Journal of Agricultural and Food Chemistry 54(I9)7355-7366

Monalisa K, Fatimawali, Gayatri C. 2013. Perbandingan hasil penetapan kadarvitamin c cangga dodol dengan menggunakan metode spektrofotometri uv-vis dan iodometri. Jurnal Ilmiah Farmasi. Vol.2 ; 2302 - 2493

Mukaromah, U. Susetyorini, S.H., Aminah, S. 20I0. Kadar vitamin $\mathrm{C}$, mutu fisik, $\mathrm{pH}$ dan mutu organoleptik sirup rosella (Hibiscus sabdariffa L.) berdasarkan cara ekstraksi. Jurnal Pangan dan Gizi. Vol I(I):43-5I.

Nurliyana, R., S. Zahir, M. Sulaeman, M.R. Aisyah, \& Rahim, K, 2010, Antioxidant Study of Pulps and Pelels of Dragon Fruit: A Comparative Study, International Food Research Journal 17:367-375

Sinaga, R.H. 20II. Studi kandungan vitamin c pada tumbuhan kol (Brassica Oleracia L.) dengan berbagai pengolahan.Skripsi.Departemen Kimia FMIPA Universitas Sumatera Utara.

Wijaya, I.P.N. 20I4.Kinetika perubahan konsentrasi asam askorbat (vitamin C) pada buah mangga podang selama penyimpanan.Jurnal Online Universitas Kadiri. 